\title{
Approaches to Respiratory and Excretion Systems Teaching: An Innovative Learning through Cirsa
}

\author{
Refirman Djamahar $^{1}$, Rizhal Hendi Ristanto ${ }^{1, *}$, Nurmasari Sartono ${ }^{1}$, Ericka Darmawan ${ }^{2}$ \\ ${ }^{1}$ Department of Biology Education, Univesitas Negeri Jakarta, Indonesia \\ ${ }^{2}$ Department of Biology Education, Universitas Tidar, Indonesia
}

Received December 2, 2019; Revised March 9, 2020; Accepted March 28, 2020

Copyright $(2020$ by authors, all rights reserved. Authors agree that this article remains permanently open access under the terms of the Creative Commons Attribution License 4.0 International License

\begin{abstract}
The purpose of this study was to analyze the effect of the cooperative integrated reading and composition learning model based scientific approach (Cirsa) and conventional learning on eighth-grade students on the subject matter of human excretory and respiratory system. Cirsa is based on constructivism learning theory that integrates the CIRC learning model with a scientific approach. The research method used was quasi-experiment using pretest-posttest non-equivalent control group design. Participants ( $\mathrm{N}=160$ students; $\mathrm{M}=95, \mathrm{~F}=65$ ) were randomly selected from junior high school. One group was assigned to Cirsa learning $(\mathrm{n}=80)$, and another group was assigned to conventional learning $(n=80)$. The conceptual of excretory and respiratory system of the human using tests with open questions were developed and used. The results showed that the Cirsa learning model was more effective than conventional learning in the subject matter of the human excretory system and the respiratory system. Based on the findings, the teachers are advised to develop the biological concept of students by using Cirsa learning, which emphasizes reading through scientifically based activities.
\end{abstract}

Keyword Biology, Cirsa, Cooperative Learning, Conceptual, Scientific Approach

\section{Introduction}

Various studies have tried to improve learning outcome on excretory system [1-4] and respiratory system [5-9]. Excretory system studies about the removal of metabolic waste substances in the form of toxic compounds such as $\mathrm{CO}_{2}, \mathrm{H}_{2} \mathrm{O}$, sweat, urine, bile, and feces. If those substances are not removed, they could disturb the function of organs in a body. Organs played a role in the human excretion system which consists of skin, kidney, lung, and hepar.

The respiratory system is an organ system used for gases exchange [5]. The system consists of various organs, such as the nasal cavity, pharynx, trachea, and pulmo $[10,11]$. Students of secondary education level study the human excretory and respiratory systems $[1,10]$. The objectives of the study include that students can analyze the human excretory and respiratory systems and understand the disturbances as well as efforts in maintaining the health of the systems $[5,6,12]$. Students are also expected to be able to create some works on human excretory and respiratory systems and are ingenious in the implementation of maintaining personal health. Students learn about those systems that consist of the constituent organs, structures, and functions, disturbances in the systems as well as efforts in maintaining the health of the systems [10].

Learning using a student-centered approach is recommended to achieve the excretory system and respiratory system learning objectives $[13,14]$. In Indonesia a new curriculum is called 2013 Curriculum, teachers must develop a student-centered Biology learning design by applying a scientific approach $[13,15,16]$. The method is integrated with learning with the expectation that students could empower various skills, knowledge and attitude to be an independent learner $[13,17,18]$. The scientific approach encompasses observing, asking, trying, reasoning, and communicating. Various benefits of the research result for learning have been stated $[13,17,19,20]$.

A learning design development by applying a learning model, strategy, and method should refer to and integrate the scientific approach [21,22]. Not all learning model could accommodate those five activities of the method; hence, integrating a learning model with a scientific approach is a necessity $[13,23]$.

The excretory and respiratory system's learning is better to be implemented using a constructivism learning that mostly involves students with the content being studied $[5,7,12,13]$. Reading activity in Biology learning is commonly recommended [14,23-25]. The advantages of reading analyzing activity in cooperative learning is a constructivism learning [26-28]. Students are given 
assignments in the group to analyze the central concept and to discuss rewrite and present their work result is believed to be able to increase the understanding of Biology concept $[13,23]$.

Cooperative Integrated Reading and Composition (CIRC) learning is one of cooperative learning models [14, 23]. It is a learning model stressing on reading and writing activities [13]. CIRC learning has not accommodated scientific activities that refer to the scientific approach $[13,14]$. Learning through a scientific approach is a learning process that is designed for students to actively construct concepts, laws or principles through the stages of the scientific approach $[13,19,20]$. The urgency of the research was related to the examining of the influence of CIRC learning integration to the scientific approach (cirsa) on the concept mastery of students who learned excretory and respiratory systems. The learning design was relevant to the learning materials and students' characteristics. This research aimed to find out the impact of Cirsa learning on the understanding of excretory system and respiratory system concepts of students.

\section{Material and Method}

\subsection{Research Design}

The research was quasi-experiment research. The research design used was a pretest-posttest non-equivalent control group design. The selection of experimental groups and control groups was not chosen randomly, then in this design both experimental and control groups were compared. The study consisted of dependent and independent variables. The independent variables included of Cirsa learning model as an experimental class and conventional learning model as a control class. The dependent variable was the understanding of the human excretory system and respiratory system concepts. The research design is described in Table 1.

Table 1. Research Design of the Randomized Pretest-Posttest Control Group.

\begin{tabular}{|c|c|c|}
\hline Pretest & Treatment & Posttest \\
\hline $\mathrm{T}_{1}$ & $\mathrm{X}_{0}$ & $\mathrm{~T}_{2}$ \\
\hline $\mathrm{T}_{3}$ & $\mathrm{X}_{1}$ & $\mathrm{~T}_{4}$ \\
\hline
\end{tabular}

Note:

$\mathrm{T}_{1,3}=$ Pretest

$\mathrm{T}_{2,4}=$ Posttest.

$\mathrm{X}_{1}=$ Cirsa learning.

$\mathrm{X}_{0}=$ Conventional learning.

\subsection{Sample Population}

The research was quantitative research. It involved 160 eighth-grade students of junior high school in Bogor, Indonesia. The sample comprised 95 male students and 65 female students. The sample was selected randomly using a grouping test, which was performing an equality test to all classes and randomly selected four classes for the research purposes. The research classes were made of two groups, namely: two (2) classes for experimental class with a total of 80 students and two (2) classes for control class with a total of 80 students.

\subsection{Research Instruments}

Instruments used in the research were syllabus, lesson plan, learners' worksheet developed by referring to Cirsa learning syntax, and Cirsa syntax implementation sheet. The instrument of the understanding of the excretory and respiratory concepts used in the research was an essay test developed by referring to the learning objectives in the 2013 Curriculum. The learning objectives are presented in Table 2. In the implementation process, learners were given a set of questions related to the understanding of the excretory system and respiratory system concepts to be completed in 50 minutes.

\subsection{Data Collection}

In the research, an instrument was developed by referring to the human excretory system and respiratory system concepts. The questions designed were by the 2013 Curriculum and the grids referred to Bloom's Taxonomy of C1 to C6. The Biology concept had eight (8) issues related to the understanding of the excretory system and respiratory system concepts. The development of questions for each thought is explained in Table 2. Students had 50 minutes to answer the questions. The quasi-experiment research took place for a month. The learners were provided an initial test on the understanding of the content concept previous to the learning and another test after they completed the knowledge.

Table 2. Learning objectives of human excretory and respiratory systems

\begin{tabular}{|c|c|c|}
\hline No & $\begin{array}{l}\text { Biology } \\
\text { content concept }\end{array}$ & Learning indicators \\
\hline 1 & $\begin{array}{l}\text { Excretory } \\
\text { system }\end{array}$ & $\begin{array}{l}\text { 1. Analyze organs in the human } \\
\text { excretory system. } \\
\text { 2. Analyze the excretory system } \\
\text { structure and function. } \\
\text { 3. Evaluate disturbances occurred in the } \\
\text { 4. Dexcretory system. } \\
\text { the health of the excretory system. }\end{array}$ \\
\hline 2 & $\begin{array}{l}\text { Respiratory } \\
\text { system }\end{array}$ & $\begin{array}{l}\text { 1. Analyze organs in the respiratory } \\
\text { system. } \\
\text { 2. Analyze the mechanism of the } \\
\text { respiratory system. } \\
\text { 3. Evaluate disturbance in the respiratory } \\
\text { system. } \\
\text { 4. Provide arguments related to } \\
\text { maintaining the health of the } \\
\text { respiratory system. }\end{array}$ \\
\hline
\end{tabular}




\subsection{Data Analysis}

The research data obtained were then analyzed using descriptive statistic of mean scores, standard deviation, and minimum and maximum values of each class. Hypothesis testing was conducted using ANCOVA. The hypothesis testing considered ANCOVA assumption requirement tests that consisted of data normality and homogeneity tests. The normality test was conducted through One-Sample Kolmogorov-Smirnov Test; whereas, the homogeneity test was done using Levene's Test of Equality of Error Variances. The tests were conducted with the assistance of a statistical analysis program of SPSS 24.0 for Mac with a significance level of $0.5 \%$.

\section{Findings}

Summary of the descriptive data processing result of excretory and respiratory system concept scores comprised pretest and posttest data is presented in Table 3.

According to the data, it can be seen that the result of
Cirsa learning model implementation had higher mean posttest in the mastery of excretory and respiratory concepts than those in a conventional model. The normality and homogeneity tests had been done using SPSS. The normality test result for posttest data group obtained a significant value (level) in all groups, which was 0.74 . The result was higher than alpha 0.05 ; thus, it can be inferred that the data were normally distributed. The homogeneity test result for posttest data obtained a significant value of 0.83 . The result was more magnificent than alpha 0.05 ; hence, the data distribution was homogeneous.

The hypothesis testing used ANCOVA test. The result is displayed in Table 4. The result of ANCOVA test on the influence of the learning model applied on excretory and respiratory systems content on conceptual understanding obtained a significant value $=0.000$, which was less than alpha $0.05(<0.05)$. Hence, it can be concluded that there was an influence of differences on the understanding of the human excretory system and respiratory system concepts on students who were taught using Cirsa and conventional learning models.

Table 3. The Descriptive data of pretest and posttest excretory system and respiratory system concepts.

\begin{tabular}{|c|c|c|c|c|c|c|c|c|}
\hline \multirow{2}{*}{ Learning } & \multicolumn{4}{|c|}{ Pretest } & \multicolumn{4}{c|}{ Posttest } \\
\cline { 2 - 9 } & Mean & Min & Max & SD & Mean & Min & Max & SD \\
\hline Conventional & 56,89 & 30,00 & 77,00 & 10,440 & 70,69 & 50,00 & 89,00 & 7,3340 \\
\hline Cirsa Model & 57,41 & 38,00 & 76,00 & 9,9996 & 85,74 & 58,00 & 99,00 & 9,1330 \\
\hline
\end{tabular}

Table 4. The influence of learning model on excretory system and respiratory system concepts.

\begin{tabular}{|l|l|l|l|l|l|}
\hline Source & Type III Sum of Squares & df & Mean Square & F & Sig. \\
\hline Corrected Model & $10319.920^{\mathrm{a}}$ & 2 & 5159.960 & 84.573 & .000 \\
\hline Intercept & 19097.466 & 1 & 19097.466 & 313.013 & .000 \\
\hline Pretest & 1259.820 & 1 & 1259.820 & 20.649 & .000 \\
\hline Learning_model & 8880.410 & 1 & 8880.410 & 145.552 & .000 \\
\hline Error & 9578.855 & 157 & 61.012 & & \\
\hline Total & 998650.000 & 160 & & & \\
\hline Corrected Total & 19898.775 & 159 & & & \\
\hline
\end{tabular}

a. R Squared $=.519($ Adjusted R Squared $=.512)$ 


\section{Discussion}

The research aimed to know the influence of Cirsa learning implementation on the understanding of the human excretory system and respiratory system concepts. The research result suggested that there was a significant difference in the mastery of biology concept between students who learned using Cirsa learning and conventional model. Students in a Cirsa class were significantly indicated a higher knowledge of Biology concept than those in the conventional learning classes. It means that Cirsa learning was proven to be more effective in improving the understanding of human excretory and respiratory systems of junior high school students. The research result is relevant to the previous research results $[2,6,12,14,29]$.

The understanding of the human excretory system and respiratory system concepts was an essential part of the mastery of natural sciences subject in school. Biology as a part of the natural sciences subject should be learned by strengthening student-centered activities [30,31], involving students in problem solving through a scientific approach [32-34] and training them through a reading activity $[13,14,35,36]$. The excretory and respiratory concepts are better learned using active learning $[1,5,6]$. Evaluation of the research referred to the revised Bloom's taxonomy levels.

Referring to the cognitive domain of the revised Bloom's taxonomy to be achieved in the understanding of human excretory system and respiratory system concepts, the learning was designed and oriented towards activities that supported the occurrence of the content mastery and process skills through a scientific event [37-39]. There was a significant difference in the mastery of Biology concept between learners who were taught by emphasizing on reading and writing activities and those by conventional learning. Learners who were taught using Cirsa learning model indicated a better concept mastery than those who were facilitated with general education [14].

Referring to the above, to the learning process and considering the unique characteristics of Cirsa learning model, it was believed that the Cirsa learning model had the potential to accommodate the learning demand. It was due to the Cirsa learning model, in its learning stages, that allows students to read more, to look for essential parts in the content, and to develop follow-up questions. Also, it will enable the occurrence of teamwork to answer questions occurred [13].

The Cirsa learning model was believed as one of the learning activity series that could encourage learners to develop knowledge and skills on Biology concept [13]. The learning model provided an opportunity for learners to submit an answer of a question, to listen to others' opinion and reflect their ideas towards other people's thoughts, which is a form of individual empowerment experience. An interactive process with peers helped the knowledge construction process. The learning model was suitable to the constructivism learning theory. Learning with constructivism allowed students to develop knowledge of human excretory and respiratory systems through various activities. The experience was built through prior knowledge, and group discussion and students had an obligation to train multiple social skills in a group work atmosphere. Students were in charge of reading the content, to be independent in solving problems in the form of reading analysis, mutually increased cooperation and achievement motivation, and improved the mastery of the concept.

Constructivist activities in Cirsa learning allowed learners to perform an independent effort to appropriately learn the content by obtaining some points of the current concept. Reading activity could stimulate students' procedural knowledge [40,41]. Procedural knowledge is one type of knowledge on performing something. Most of the experience is represented by the capability of taking the content essence, knowing how to simplify information presented in the content and taking the points of the material. Through the use of a strategy that develops skills of summarizing content and reviewing the reading sources will improve students' conceptual understanding $[23,42,43]$. Biology content in junior high school that is incorporated in the natural sciences content have a general characteristic of theoretical reading and concepts, so as in the excretory system and respiratory system content [13]. Both have many concepts and reading description; thus, it requires a learning model that is able to lead students to succeed in learning. The Cirsa stage is believed to be able to do it.

In the first Cirsa learning stage, students were divided into groups of 4-6 students. The syntax conveyed the learning objectives and then correlated teaching materials to learning media that could describe content to be determined by the students. The learning media to be displayed, in the form of PowerPoint, video or props, was expected to trigger students to start performing initial observation on the learning content of excretory and respiratory systems in junior high school students.

Cirsa learning model also accommodated learners' learning activities through cooperative work by providing an opportunity to deliver as well as listen to some ideas and reflect the opinions as a form of individual empowerment experience $[14,44,45]$. Discussion activities with the group could help the knowledge construction process [14]. Social interaction played an essential role in cognition formation [43]. Students who learn Biology through group activities could improve inter-students relations in the groups $[13,14,26]$ and it could stimulate activities that lead to peer tutor from the learners who have better academic ability than other students.

In the second learning stage, teachers would allow students to read and conduct group discussion, and together, they would find the central concept of the learning content. 
Through a scientific approach, the target for students was their ability to explore and associate. In the reading analysis stage, learners researched and looked for important information from the content in human excretory and respiratory systems. Students organized the content being studied by exploring various sources. In the next step, students rewrote on the worksheet. The activity was believed to be able to activate prior knowledge, to sort out content that was considered to be suitable for the construction of content knowledge being studied $[36,46,47]$.

In a stage of writing questions occurred after group discussion activity, students were trained to ask questions related to human excretory and respiratory systems. The action was deemed to be an effort to make the knowledge on excretory and respiratory systems perfect. Students who were trained to write questions could help in identifying Biology learning requirements $[39,43,48]$. Writing questions could also help students to make a decision and solve problems, and in the end, they would be able to integrate and create new concepts relationship [26]. The learning condition created by the Cirsa learning model was confirmed to be able to hierarchically and systematically build thinking ability on excretory and respiratory systems; hence, it was easier for the new knowledge to associate with the old knowledge.

The last activity of the Cirsa learning model was cooperative group presentation. Learning in a collaborative group requires teachers to train students to be able to communicate well and direct them to discuss correctly and sequentially and provide constructive feedback for each other [14,49]. The activity was beneficial for the construction of cognitive understanding in the excretory system and respiratory system content for learners. The scientific approach expected to emerge from the learners was a skill to communicate according to the mandate of the national education curriculum of Indonesia (Kurikulum 2013 revision).

According to the mandate of the 2013 Curriculum, group presentation and scientific approach combination are expected to give rise of communication ability from the learners. During the group presentation, students will teach each other (to give each other skill, understanding, and experience through the activity principle of responding to the answers and questions that occur in the class discussion). A learning activity should pay attention to interaction and relationship between students, students' motivation, and the relationship between students and teacher [50]. A learning step that conditioning students to communicate with each other is the representation of cooperative learning that is imperative in training learners to improve their learning skill since there is knowledge activation aspect in communicating through presentation activity and in the end, they could master the concept well $[23,40,50]$.

During the communication process, concept understanding reflection activation occurs, which is a self-examine process and generates questions on self-correct thinking $[51,52,54]$. Reflection skill on the concept of understanding constitutes activities of control, monitor, and self-regulation that occur during learning and problem-solving. Several studies indicate that self-regulation in education has been used to improve academic achievement [53]. The applied learning model is not only to convey content but also to train students' thinking ability so they could use their cognitive structure completely and directly [42]. The Cirsa learning model in the research had another purpose besides conveying subject content, which was to train students' metacognitive skill.

The research finding for Biology learning implies that the improvement of concept mastery on the excretory and respiratory systems can be made through the involvement of learners incomplete assignments. Through the reading activity, discussion, writing, and communicating the result, students' biology understanding could be improved effectively. Providing jobs for students to learn human excretory and respiratory systems by familiarizing students through the activity of asking question or problem after analysis, synthesis, and evaluation activities in a group learning environment could facilitate students to improve the mastery of excretory system and respiratory system concept and could improve students' problem-solving skill.

\section{Conclusions}

Cirsa learning was proven to be more effective in improving junior high school students' understanding of human excretory and respiratory systems. In the relevant learning content, learning that integrates group reading is recommended by modifying it based on the scientific approach.

\section{Acknowledgements}

This work was supported by the Directorate of Research and Community Service (DRPM), Ministry of Research, Technology, and Higher Education (Kemenristekdikti), Indonesia under grant number 9/SP2H/DRPM/LPPMUNJ/III/2-2019.

\section{REFERENCES}

[1] Qumillaila, Q., Susanti, B. H., \& Zulfiani, Z. (2017). Pengembangan augmented reality versi android sebagai media pembelajaran sistem ekskresi manusia. Jurnal Cakrawala Pendidikan, 36(1), 57-69. https://doi.org/10.21 831/cp.v36i1.9786. 
[2] Sungur, S., Tekkaya, C., \& Geban, Ö. (2006). Improving achievement through problem-based learning. Journal of Biological Education, 40(4), 155-160. https://doi.org/10.1 080/00219266.2006.9656037

[3] Inel, D., \& Balim, A. G. (2010). The effects of using problem-based learning in science and technology teaching upon students' academic achievement and levels of structuring concepts. Asia-Pacific Forum on Science Learning and Teaching, 11(2), 1-23.

[4] Kostova, Z., \& Radoynovska, B. (2010). Motivating students' learning using word association test and concept maps. Bulgarian Journal of Science \& Education Policy, 4(1), 62-98.

[5] Hernandez, A. M., Mañanas, M. A., \& Costa-Castelló, R. (2008). Learning respiratory system function in BME studies by means of a virtual laboratory: RespiLab. IEEE Transactions on Education, 51(1), 24-34. https://doi.org/1 0.1109/TE.2007.893355

[6] Rao, S. P., \& DiCarlo, S. E. (2017). Active learning of respiratory physiology improves performance on respiratory physiology examinations. Advances in Physiology Education, 25(2), 55-61. https://doi.org/10.115 2/advances.2001.25.2.55

[7] Azer, S. A. (2015). Is wikipedia a reliable learning resource for medical students? evaluating respiratory topics. Advances in Physiology Education, 39(1), 5-14.https://doi .org/10.1152/advan.00110.2014

[8] Khasanah, A. N., Sajidan, S., \& Widoretno, S. (2017). Effectiveness of critical thinking indicator-based module in empowering student's learning outcome in respiratory system study material. Jurnal Pendidikan IPA Indonesia, 6(1), 187-195. https://doi.org/10.15294/jpii.v6i1.8490.

[9] Mayer, R. E. (2008). Applying the science of learning: evidence-based principles for the design of multimedia instruction. American Psychologist, 63(8), 760-769. https://doi.org/10.1037/0003-066X.63.8.760.

[10] Nurmadani, S., \& Samsulhadi, S. (2010). Ilmu pengetahuan alam (terpadu). Jakarta: Grahadi.

[11] Campbell, P. (1992). Biochemistry and molecular biology. Biochemical Education, 20(3), 158-165. https://doi.org/10. 1016/0307-4412(92)90061-P

[12] Aydin, S. (2016). To what extent do Turkish high school students know about their body organs and organ systems? International Journal of Human Sciences, 13(1), 1094. https://doi.org/10.14687/ijhs.v13i1.3498

[13] Djamahar, R., Ristanto, R. H., Sartono, N., Ichsan, I. Z., \& Muhlisin, A. (2018). Cirsa: Designing instructional kits to empower 21 st century skill. Educational Process: International Journal, 7(3), 200-208. https://doi.org/10.22 521/edupij.2018.73.4.

[14] Ristanto, R. H., Zubaidah, S., Amin, M., \& Rohman, F. (2017). Scientific literacy of students learned through guided inquiry. International Journal of Research \& Review, 234(5), 23-30.

[15] Sudiyanto, G., Sutadji, E., \& Rudiyanto, E. (2017). Implementasi penilaian autentik kurikulum 2013 pada rapor online di smk negeri 6 malang. Jurnal Dinamika Vokasional
Teknik Mesin, 1(1), 51-56.https://doi.org/10.21831/dinami ka.v1i1.11457.

[16] Miarsyah, M., Ristanto, R.H., Nurhayati, Mufida, S.N., Suparini, Zharroh, A.E. (2020). Development of adobe flash media integrated into hots on circulation system (af-hots bicycle media). International Journal of Advanced Trends in Computer Science and Engineering, 9(1), 896-903. https://doi.org/10.30534/ijatcse/2020/128912020.

[17] Kinay, I., \& Bagceci, B. (2016). The Investigation of the Effects of Authentic Assessment Approach on Prospective Teachers' Problem-Solving Skills. International Education Studies, 9(8), 51. https://doi.org/10.5539/ies.v9n8p51.

[18] Astriyandi, A., Chotimah, U., \& Faisal, E. El. (2016). Kemampuan guru menerapkan penilaian autentik dalam pembelajaran ppkn. Jurnal Bhineka Tunggal Ika, 3(2), 187198.

[19] Ristanto, R. H., \& Djamahar, R. (2019). Penguatan keterampilan penilaian autentik guru ipa biologi di kabupaten bogor. BAKTIMAS: Jurnal Pengabdian pada Masyarakat, 1(1), 61-69.

[20] Djamahar, R., Ristanto, R. H., Sartono, N., Ichsan, I. Z., Darmawan, E., \& Muhlisin, A. (2019). Empowering Student's Metacognitive Skill Through Cirsa Learning. Journal of Physics: Conference Series, 1227(1), 012001.

[21] Machin, A. (2014). Implementasi pendekatan saintifik, penanaman karakter dan konservasi pada pembelajaran materi pertumbuhan. Jurnal Pendidikan IPA Indonesia, 3(1) $28-35$

[22] Proulx, G. (2012). Integrating scientific method \& critical thinking in classroom debates on environmental issues. The American Biology Teacher, 66(1), 26-33. https://doi.org/1 $0.2307 / 4451613$

[23] Ristanto, R. H., Zubaidah, S., Amin, M., \& Rohman, F. (2018). From a reader to a scientist: developing cirgi learning to empower scientific literacy and mastery of biology concept. Biosfer: Jurnal Pendidikan Biologi, 11(2), 78-89. https://doi.org/10.21009/biosferjpb.v11n2.90-100.

[24] Stacey, K. (2010). Mathematical and scientific literacy around the world. Journal of Science and Mathematics Education in Southeast Asia, 33(1), 1-16.

[25] Leasa, M., Sanabuky, Y. L., Batlolona, J. R., \& Enriquez, J. J. (2019). Jigsaw in teaching circulatory system: a learning activity on elementary science classroom. Biosfer: Jurnal Pendidikan Biologi, 12(2), 122-134.

[26] Darmawan, E., Zubaidah, S., Susilo, H., \& Suwono, H. (2016). Simas eric Model to Improve Students' Critical Thinking Skills Faculty of Mathematics and Science. Journal of Education \& Social Policy, 3(6), 45-53

[27] Klymkowsky, M. W., Garvin-Doxas, K., \& Zeilik, M. (2003). Bioliteracy and teaching efficacy: What biologists can learn from physicists. Cell Biology Education, 2, 155-161. https://doi.org/10.1187/cbe.03-03-0014.

[28] Ristanto, R. H., Zubaidah, S., Amin, M., \& Rohman, F. (2017). Scientific literacy of students learned through guided inquiry. International Journal of Research \& Review, 234(5), 23-30.

[29] Alparslan, C., Tekkaya, C., \& Geban, Ö. (2003). Using the 
conceptual change instruction to improve learning. Journal of Biological Education, 37(3), 133-137. https://doi.org/10 $.1080 / 00219266.2003 .9655868$.

[30] Fuad, N. M., Zubaidah, S., Mahanal, S., \& Suarsini, E. (2017). Improving junior high schools' critical thinking skills based on test three different models of learning. International Journal of Instruction, 10(1), 101-116. https://doi.org/10.12973/iji.2017.1017a

[31] Lestari, P., Ristanto, R. H., \& Miarsyah, M. (2019). Metacognitive and conceptual understanding of pteridophytes: Development and validity testing of an integrated assessment tool. Indonesian Journal of Biology Education, 2(1), 15-24.

[32] Wurdinger, S., \& Qureshi, M. (2015). Enhancing college students' life skills through project based learning. Innovative Higher Education, 40(3), 279-286. https://doi.o $\mathrm{rg} / 10.1007 / \mathrm{s} 10755-014-9314-3$.

[33] Tsai, C.-W., Shen, P.-D., \& Lin, R.-A. (2014). Exploring the Effects of Student-Centered Project-Based Learning with Initiation on Students' Computing Skills. International Journal of Information and Communication Technology Education, 11(1), 27-43. https://doi.org/10.4018/ijicte.201 5010102.

[34] Afandi. (2011). Pembelajaran biologi menggunakan pendekatan metakognitif melalui model reciprocal taching dan problem based learning ditinjau dari kemandirian belajar dan kemampuan berpikir kritis mahasiswa. Jurnal Pendidikan Matematika Dan IPA, 2(2), 1-12.https://doi.or g/10.26418/jpmipa.v2i2.2182.

[35] Chin, C. C., Yang, W. C., \& Tuan, H. L. (2016). Argumentation in a socioscientific context and its influence on fundamental and derived science literacies. International Journal of Science and Mathematics Education, 14(4), 603-617. https://doi.org/10.1007/s10763-014-9606-1.

[36] Sørvik, G. O., \& Mork, S. M. (2015). Scientific literacy as social practice: Implications for reading and writing in science classrooms. Nordic Studies in Science Education, 11(3), 268-281.

[37] Lestari, P., Ristanto, R. H., \& Miarsyah, M. (2019). Analysis of conceptual understanding of botany and metacognitive skill in pre-service biology teacher in Indonesia. Journal for the Education of Gifted Young Scientists, 7(2), 199-214.

[38] Yunanda, I., Susilo, H., \& Ghofur, A. (2019). Misconceptions identification on biodiversity and protist using multiple choice open reason (mcor). Biosfer: Jurnal Pendidikan Biologi, 12(2), 170-181.

[39] Indriani, D., \& Mercuriani, I. S. (2019). Experiential learning model with mind mapping on fungi: how to improve science process skills? Biosfer: Jurnal Pendidikan Biologi, 12(2), 223-237.

[40] Darmawan, E., Wahono, B., Sukmawati, I., Alamsyah, M. R. N., Permadani, K. G., Pamungkas, S. J., ... Zamzami, M. R. A. (2019). Integrating Simas eric with google classroom: enhancing biology students' motivation and scientific writing. Biosfer: Jurnal Pendidikan Biologi, 12(1), 1-12. https://doi.org/10.21009/biosferjpb.v12n1.1-12.

[41] Rittle-Johnson, B., Fyfe, E. R., \& Loehr, A. M. (2016). Improving conceptual and procedural knowledge: The impact of instructional content within a mathematics lesson.
British Journal of Educational Psychology, 86(4), 576-591. https://doi.org/10.1111/bjep.12124

[42] Setiawati, H., \& Corebima, A. D. (2017). Empowering critical thinking skills of the students having different academic ability in biology learning of senior high school through pq4r-tps strategy. The International Journal of Social Sciences and Humanities Invention, 4(5), 3521-3526. https://doi.org/10.18535/ijsshi/v4i5.09

[43] Darmawan, E., Brasilita, Y., Zubaidah, S., \& Saptasari, M. (2018). Meningkatkan keterampilan metakognitif siswa berbeda gender dengan model pembelajaran simas eric di sman 6 malang. Biosfer: Jurnal Pendidikan Biologi, 11(1), 47-56. Retrieved from https://doi.org/10.21009/biosferjpb. $11-1.5$

[44] Supriyatin, Rahayu, S., Ristanto, R.H., Ichsan, I.Z. (2019). Improving hots in biology learning: A supplement book of plant growth and development. Universal Journal of Educational Research, 7(12), 2642-2646.

[45] Baloche, L., \& Brody, C. M. (2017). Cooperative learning: exploring challenges, crafting innovations. Journal of Education for Teaching, 43(3), 274-283. https://doi.org/10 $.1080 / 02607476.2017 .1319513$.

[46] Jiménez-Taracido, L., Manzanal Martinez, A. I., \& Baridon Chauvie, D. G. (2019). Reading literacy and metacognition in a Spanish adult education center. European Journal for Research on the Education and Learning of Adults, 10(1), 29-46. https://doi.org/10.3384/rela.2000-7426.ojs169.

[47] Mudra, H. (2018). Metacognitive online reading strategies among pre-service efl teachers in Indonesia. Educational Process International Journal, 7(2), 151-164. https://doi.o $\mathrm{rg} / 10.22521$ /edupij.2018.72.5.

[48] Sobel, J. M., Chen, G. F., Watt, L. R., \& Schemske, D. W. (2010). The biology of speciation. Evolution: International Journal of organic evolution, 64(2), 295-315.

[49] Fung, D. C. L., To, H., \& Leung, K. (2016). The influence of collaborative group work on students' development of critical thinking: The teacher's role in facilitating group discussions. Pedagogies, 11(2), 146-166. https://doi.org/1 0.1080/1554480X.2016.1159965.

[50] Ristanto, R. H,. Miarsyah, M., Muharomah, D.R., Astuti, T.A., Aini, S., \& Prihatin., A.I (2019). Light-Board: simple media to learn photosynthesis concepts. International Journal of Advanced Trends in Computer Science and Engineering, 9(1), 299-303. https://doi.org/10.30534/ijatcse/2020/45912020

[51] Lai, C. L., \& Hwang, G. J. (2016). A self-regulated flipped classroom approach to improving students' learning performance in a mathematics course. Computers and Education, 100, 126-140.https://doi.org/10.1016/j.comped u.2016.05.006

[52] Allo, E. L., Permanasari, A., \& Redjeki, S. (2019). The development of rubric to assess metacognition knowledge. Advances in Social Science, Education and Humanities Research, 253(3), 549-552.

[53] Dent, A. L., \& Koenka, A. C. (2016). The relation between self-regulated learning and academic achievement across childhood and adolescence: A Meta-Analysis. Educational Psychology Review, 28(3), 4250474. https://doi.org/10.100 7/s10648-015-9320-8. 